УДК 346.9

DOI https:/ / doi.org/10.32837/yuv.v0i1.1643

\author{
Д. Комарницький, \\ аспірант \\ ДВНЗ «Київський національний економічний університет \\ імені Вадима Гетьмана»
}

\title{
ВІДПОВІДАЛЬНІСТЬ СУБ'ЄКТІВ ЗОВНІШНЬОЕКОНОМІЧНОї ДІЯЛЬНОСТІ В УКРАЇНІ
}

Україна як держава і всі суб'єкти зовнішньоекономічної діяльності та іноземні суб'єкти господарської діяльності несуть відповідальність за порушення зовнішньоекономічного законодавства та / або своїх зобов'язань, які випливають із договорів (контрактів), на умовах i в порядку, визначених законами України [4]. Дослідження відповідальності суб'єктів зовнішньоекономічної діяльності спрямоване на удосконалення механізмів державного та недержавного регулювання зовнішньоекономічних відносин, забезпечення законності у здійсненні зовнішньоекономічних операцій.

Питання правового регулювання та державного управління у сфері зовнішньоекономічної діяльності вже були предметом дослідження в різних галузях юридичної науки $[1 ; 2]$. Однак дослідження відповідальності суб'єктів зовнішньоекономічної діяльності в Україні потребують подальшого розвитку 3 огляду на їх актуальність для реалізації державної політики щодо забезпечення законності та правопорядку у зовнішньоекономічних відносинах.

Завданням статті $€$ дослідження питань відповідальності суб'єктів зовнішньоекономічної діяльності в Україні.

Юридична відповідальність - це вид соціальної відповідальності, сутність якої полягає у застосуванні до правопорушників (фізичних і юридичних осіб) передбачених законодавством санкцій, що забезпечуються у примусовому порядку державою [3].

Загальні засади відповідальності суб'єктів зовнішньоекономічної діяль- ності визначаються у Розділі VI Закону України «Про зовнішньоекономічну діяльність» [4].

Як вже зазначалося вище, Україна як держава і всі суб'єкти зовнішньоекономічної діяльності та іноземні суб'єкти господарської діяльності несуть відповідальність за порушення Закону України «Про зовнішньоекономічну діяльність» або пов'язаних із ним законів України та / або своїх зобов'язань, які випливають із договорів (контрактів), тільки на умовах i в порядку, визначених законами України. Україна як держава не несе відповідальності за дії суб' $є$ ктів зовнішньоекономічної діяльності, а суб'єкти зовнішньоекономічної діяльності не несуть відповідальності за дії України як держави. Якщо Україна бере участь у зовнішньоекономічній діяльності як суб'єкт такої діяльності, то вона несе відповідальність на загальних і рівноправних засадах з іншими суб'єктами зовнішньоекономічної діяльності [4].

Всі справи та питання щодо визначення відповідальності, що виникають при застосуванні Закону України «Про зовнішньоекономічну діяльність» i пов'язаних із ним законів України, підсудні судовим органам України. Суб'єкти зовнішньоекономічної діяльності та іноземні суб'єкти господарської діяльності мають право на судовий розгляд зазначених справ і питань.

Особливості відповідальності Україн як держави визначені у ст. 34 Закону України «Про зовнішньоекономічну діяльність». Так, Україна як держава несе майнову відповідальність у пов- 
ному обсязі перед суб'єктами зовнішньоекономічної діяльності та іноземними суб'єктами господарської діяльності за всі свої дії, що суперечать чинним законам України і спричиняють збитки (прямі, побічні), моральну шкоду цим суб'єктам і призводять до втрати ними вигоди, а також за інші свої дії, в т. ч. й ті, які регулюють зовнішньоекономічну діяльність і прямо не передбачені в Законі України «Про зовнішньоекономічну діяльність», що спричиняють зазначені збитки (шкоду) та призводять до втрати вигоди, крім випадків, коли такі дії зумовлені неправомірними діями зазначених суб'єктів зовнішньоекономічної діяльності та іноземних суб'єктів господарської діяльності. Україна як держава відповідає за вищевказані дії всім своїм майном [4].

Дії державних органів та офіційних службових осіб цих органів вважаються діями України як держави загалом, і держава несе за них відповідальність, як зазначено вище. Будь-який суб'єкт зовнішньоекономічної діяльності або іноземний суб'єкт господарської діяльності має право подати позов до України як держави. Зазначені позови підсудні судам України відповідно до ст. 39 Закону України «Про зовнішньоекономічну діяльність». Зазначені позови подаються суб'єктами зовнішньоекономічної діяльності за місцем ïх постійного знаходження або проживання, іноземними суб'єктами господарської діяльності - за місцезнаходженням державного органу та / або службової особи, що вчинили протиправні дії. Позов подається у загальному порядку, визначеному цивільно-процесуальним законодавством України. Від імені України як держави у процесі виступають державний орган та / або службова особа, вказані у позові. Слід зазначити, що Україна як держава має право на регресне відшкодування своїх збитків, які виникли внаслідок задоволення зазначених позовів із боку державних органів та / або службових осіб за рахунок їх майна (відповідно балансового або власного) [4].
Щодо відповідальності інших суб'єктів зовнішньоекономічної діяльності слід зазначити, що вони несуть відповідальність у видах і формах, передбачених ст. 33 Закону України «Про зовнішньоекономічну діяльність», іншими законами України та / або зовнішньоекономічними договорами (контрактами). Порядок притягнення до відповідальності, здійснення відповідальності та звільнення від відповідальності визначається процесуальними законами України. Порядок притягнення до цивільно-правової відповідальності, здійснення такої відповідальності та звільнення від неї може визначатися зовнішньоекономічними договорами (контрактами), якщо це не суперечить чинним законам України [4].

Види та форми відповідальності у зовнішньоекономічній діяльності визначаються у ст. 33 Закону України «Про зовнішньоекономічну діяльність». Так, у сфері зовнішньоекономічної діяльності застосовуються такі види відповідальності: майнова і кримінальна.

Майнова відповідальність має цивільно-правовий характер, і їі засади визначаються Цивільним кодексом України [5], Законами України «Про зовнішньоекономічну діяльність» [4], «Про міжнародне приватне право» (встановлює порядок урегулювання приватноправових відносин, які хоча б через один із своїх елементів пов'язані з одним або кількома правопорядками, іншими, ніж український правопорядок) [6] та іншими законами України. Застосування цивільно-правової відповідальності завжди пов'язане із втратами майнового характеру в майновій сфері боржника (відшкодуванням заподіяної майнової або моральної шкоди, сплатою неустойки - штрафу, пені). Залежно від підстав застосування розрізняють договірну i позадоговірну (деліктну) цивільну відповідальність.

Майнова відповідальність застосовується у формі матеріального відшкодування прямих, побічних збитків, упущеної вигоди, матеріального відшкодування моральної шкоди, а також 
майнових санкцій. Якщо порушення суб'єктами зовнішньоекономічної діяльності або іноземними суб'єктами господарської діяльності Закону Украіни «Про зовнішньоекономічну діяльність» або пов'язаних із ним законів України призвели до виникнення збитків, втрати вигоди та / або моральної шкоди у інших таких суб'єктів або держави, суб'єкти, що порушили закон, несуть матеріальну відповідальність у повному обсязі [4].

Кримінальна відповідальність у зовнішньоекономічній діяльності запроваджується тільки у випадках, передбачених кримінальним законодавством України. Підставою кримінальної відповідальності $€$ вчинення особою суспільно небезпечного діяння, яке містить склад злочину, передбаченого Кримінальним кодексом України [7]. Кримінальна відповідальність настає за вчинення злочинів проти основ національної безпеки України; проти життя та здоров'я особи; проти волі, честі та гідності особи; проти статевої свободи та статевої недоторканності особи; проти виборчих, трудових та інших особистих прав і свобод людини і громадянина; проти власності; у сфері господарської діяльності; проти довкілля; проти громадської безпеки; проти безпеки виробництва; проти безпеки руху й експлуатації транспорту; проти громадського транспорту та моральності; у сфері обігу наркотичних засобів, психотропних речовин, їх аналогів або прекурсорів та інші злочини проти здоров'я населення; у сфері охорони державної таємниці, недоторканності державних кордонів, забезпечення призову та мобілізації; проти авторитету органів державної влади, органів місцевого самоврядування, об'єднань громадян і злочини проти журналістів; у сфері використання електронно-обчислювальних машин (комп'ютерів), систем і комп'ютерних мереж і мереж електрозв'язку; у сфері службової діяльності та професійної діяльності, пов'язаної з наданням публічних послуг; проти правосуддя; проти вста- новленого порядку несення військової служби (військові злочини); проти миру, безпеки людства та міжнародного правопорядку [7].

Видами покарань згідно зі ст. 51 Кримінального кодексу України є штраф; позбавлення військового, спеціального звання, рангу, чину або кваліфікаційного класу; позбавлення права обіймати певні посади або займатися певною діяльністю; громадські роботи; виправні роботи; службові обмеження для військовослужбовців; конфіскація майна; арешт; обмеження волі; тримання в дисциплінарному батальйоні військовослужбовців; позбавлення волі на певний строк; довічне позбавлення волі [7].

Вище вже зазначалося, що відповідно до ст. 33 Закону України «Про зовнішньоекономічну діяльність» у сфері зовнішньоекономічної діяльності застосовуються такі види відповідальності, як майнова та кримінальна.

Виходячи 3 того, що зовнішньоекономічна діяльність є одним із видів господарської діяльності та врегульована нормами Господарського кодексу України (Розділ VII «Зовнішньоекономічна діяльність»), можна зробити висновок про те, що суб'єкти зовнішньоекономічної діяльності несуть, крім цивільно-правової, також і господарсько-правову майнову відповідальність, норми про яку містяться у Розділі V «Відповідальність за правопорушення у сфері господарювання» Господарського кодексу України. Підставою господарсько-правової відповідальності учасника господарських відносин $€$ вчинене ним правопорушення у сфері господарювання [8].

Господарські санкції застосовуються до правопорушників на підставах і в порядку, передбачених Господарським кодексом України, іншими законами та договором. Господарськими санкціями визнаються заходи впливу на правопорушника у сфері господарювання, внаслідок застосування яких для нього настають несприятливі економічні та / або правові 
наслідки. У сфері господарювання застосовуються такі види господарських санкцій: відшкодування збитків; штрафні санкції; оперативно-господарські санкції. Господарські санкції застосовуються у встановленому законом порядку за ініціативою учасників господарських відносин, а адміністративно-господарські санкції - уповноваженими органами державної влади або органами місцевого самоврядування (ст. 216-218 Господарського кодексу України) [8].

До штрафних санкцій належать господарські санкції у вигляді грошової суми (неустойка, штраф, пеня), яку учасник господарських відносин зобов'язаний сплатити у разі порушення ним правил здійснення господарської діяльності, невиконання або неналежного виконання господарського зобов'язання (ст. 230 Господарського кодексу України) [8].

Оперативно-господарські

санкціï - це заходи оперативного впливу на правопорушника 3 метою припинення або попередження повторення порушень зобов'язання, що використовуються самими сторонами зобов'язання в односторонньому порядку. До суб'єкта, котрий порушив господарське зобов'язання, можуть бути застосовані лише ті оперативно-господарські санкції, застосування яких передбачено договором. Оперативно-господарські санкції застосовуються незалежно від вини суб'єкта, який порушив господарське зобов'язання. У господарських договорах сторони можуть передбачати використання таких видів оперативно-господарських санкцій: односторонньої відмови від виконання свого зобов'язання управненою стороною, зі звільненням іiі від відповідальності за це - у разі порушення зобов'язання другою стороною; відмови від оплати за зобов'язанням, яке виконано неналежним чином або достроково виконано боржником без згоди другої сторони; відстрочення відвантаження продукції чи виконання робіт внаслідок прострочення виставлення акредитива платником, припинення видачі банківських позичок тощо; відмови управненої сторони зобов'язання від прийняття подальшого виконання зобов'язання, порушеного другою стороною, або повернення в односторонньому порядку виконаного кредитором за зобов'язанням; встановлення в односторонньому порядку на майбутне додаткових гарантій належного виконання зобов'язань стороною, котра порушила зобов'язання: зміна порядку оплати продукції (робіт, послуг), переведення платника на попередню оплату продукції (робіт, послуг) або на оплату після перевірки їх якості тощо; відмови від встановлення на майбутнє господарських відносин зі стороною, яка порушує зобов'язання. Наведений перелік не $€$ вичерпним і сторони можуть передбачити у договорі також інші оперативно-господарські санкції (ст. 236 Господарського кодексу України) [8].

Крім зазначених вище санкцій, до суб'єктів господарювання можуть бути застосовані уповноваженими органами державної влади або органами місцевого самоврядування адміністративно-господарські санкції - заходи організаційно-правового або майнового характеру, спрямовані на припинення правопорушення суб'єкта господарювання та ліквідацію його наслідків, а саме: вилучення прибутку (доходу); адміністративно-господарський штраф; стягнення зборів (обов'язкових платежів); застосування антидемпінгових заходів; припинення експортно-імпортних операцій; застосування індивідуального режиму ліцензування на умовах і в порядку, визначених законом; зупинення дії ліцензіі (патенту) на здійснення суб'єктом господарювання певних видів господарської діяльності; анулювання ліцензіі (патенту) на здійснення суб'єктом господарювання окремих видів господарської діяльності; обмеження або зупинення діяльності суб'єкта господарювання; ліквідація суб'єкта господарювання; інші адміністративно-господарські санкції, встановлені Господарським 
кодексом України та іншими законами (ст. 239 Господарського кодексу України) [8].

Враховуючи комплексний характер зовнішньоекономічних відносин, їх суб'єкти можуть також притягуватися і до адміністративної відповідальності. Відповідно до ст. 2 Кодексу України про адміністративні правопорушення [9] законодавство України про адміністративні правопорушення складається з цього кодексу та інших законів про адміністративні правопорушення, які до включення їх у встановленому порядку до зазначеного кодексу застосовуються безпосередньо. Положення Кодексу України про адміністративні правопорушення поширюються i на адміністративні правопорушення, відповідальність за вчинення яких передбачена законами, ще не включеними до цього кодексу [9].

Питання щодо адміністративної відповідальності за порушення митних правил регулюються Митним кодексом України [10].

Згідно зі ст. 9 Кодексу України про адміністративні правопорушення адміністративним правопорушенням (проступком) визнається протиправна, винна (умисна або необережна) дія чи бездіяльність, яка посягає на громадський порядок, власність, права і свободи громадян, на встановлений порядок управління і за яку законом передбачено адміністративну відповідальність [9].

Правопорушеннями, за які настає адміністративна відповідальність, є правопорушення в галузі охорони праці та здоров'я населення; що посягають на власність; у сфері охорони природи, використання природних ресурсів, охорони культурної спадщини; у промисловості, будівництві й у сфері використання паливно-енергетичних ресурсів; у сільському господарстві та за порушення ветеринарно-санітарних правил; на транспорті, в галузі шляхового господарства і зв'язку; в галузі житлових прав громадян, житлово-комунального господарства та благоустрою; в галузі торгівлі, громадського харчування, сфері послуг, у галузі фінансів і підприємницькій діяльності; в галузі стандартизації, якості продукції, метрології та технічного регулювання; пов'язані з корупцією; військові адміністративні правопорушення; що посягають на громадський порядок і громадську безпеку; які посягають на встановлений порядок управління; що посягають на здійснення народного волевиявлення та встановлений порядок його забезпечення [9].

За вчинення адміністративних правопорушень можуть застосовуватися такі адміністративні стягнення, як попередження; штраф; штрафні бали; оплатне вилучення предмета, який став знаряддям вчинення або безпосереднім об'єктом адміністративного правопорушення; конфіскація: предмета, що став знаряддям вчинення або безпосереднім об'єктом адміністративного правопорушення; грошей, одержаних внаслідок вчинення адміністративного правопорушення; позбавлення спеціального права, наданого громадянинові (права керування транспортними засобами, права полювання); позбавлення права обіймати певні посади або займатися певною діяльністю; громадські роботи; виправні роботи; суспільно корисні роботи; адміністративний арешт; арешт з утриманням на гауптвахті. Законами України може бути встановлено й інші види адміністративних стягнень [9].

Законами України може бути передбачено адміністративне видворення за межі України іноземців і осіб без громадянства за вчинення адміністративних правопорушень, які грубо порушують правопорядок.

Суб'єкти зовнішньоекономічної діяльності України та іноземні суб'єкти господарської діяльності несуть відповідальність за порушення зовнішньоекономічного законодавства та / або своїх зобов'язань, що випливають із договорів (контрактів), на умовах і в порядку, визначених законами України. У сфері зовнішньоекономічної діяльності засто- 
совуються такі види відповідальності, як майнова (цивільно-правова та господарсько-правова), адміністративна та кримінальна [4]. Дослідження відповідальності суб'єктів зовнішньоекономічної діяльності потребують подальшого розвитку з огляду на їх актуальність для реалізації державної політики щодо забезпечення законності та правопорядку у сфері зовнішньоекономічних відносин.

У статmі досліджуються питання відповідальності суб'єктів зовнішньоекономічної діяльності в Україні. У сфері зовнішньоекономічної діяльності застосовуються майнова (цивільно-правова та господарсько-правова), адміністративна та кримінальна відповідальність. Дослідження відповідальності суб'єктів такої діяльності сприяють реалізаизї державної політики забезпечення законності у сфері зовнішньоекономічних відносин.

Майнова відповідальність застосовується у формі матеріального відикодування прямих, побічних збитків, упущеної вигоди, матеріального відикодування моральної шкоди, а також майнових санкцій.

Кримінальна відповідальність у зовнішньоекономічній діяльності запроваджується тільки у випадках, передбачених кримінальним законодавством України. Підставою кримінальної відповідальності є вчинення особою суспільно небезпечного діяння, яке містить склад злочину, передбаченого Кримінальним кодексом України.

Господарські санкиії застосовуються до правопорушників на підставах $i$ в порядку, передбачених Господарським кодексом України, іншими законами та договором. Господарськими санкціями визнаються заходи впливу на правопорушника у сфері господарювання, внаслідок застосування яких для нього настають несприятливі економічні та / або правові наслідки. У сфері госпо- дарювання застосовуються такі види господарських санкцій: відикодування збитків; итрафні санкиіі; оперативно-господарські санкції. Господарські санкції застосовуються у встановленому законом порядку за ініціативою учасників господарських відносин, а адміністративно-господарські санкціі - уповноваженими органами державної влади або органами місцевого самоврядування (cm. 216-218 Господарського кодексу України).

Правопорушеннями, за які настає адміністративна відповідальність, $\epsilon$ правопорушення в галузі охорони праці та здоров'я населення; що посягають на власність; у сфері охорони природи, використання природних ресурсів, охорони культурної спадщини; у промисловості, будівництві й у сфері використання паливно-енергетичних ресурсів; у сільському господарстві та за порушення ветеринарно-санітарних правил; на транспорті, в галузі шляхового господарства $i$ зв'язку; в галузі житлових прав громадян, житлово-комунального господарства та благоустрою та ін.

Ключові слова: юридична відповідальність, зовнішньоекономічна діяльність, цивільно-правова відповідальність, господарсько-правова відповідальність, адміністративна відповідальність, кримінальна відповідальність.

Komarnitskiy D. Responsibility of foreign economic activities in Ukraine

This article explores the issues of responsibility of foreign economic operators in Ukraine. In the sphere of foreign economic activity, property (civil and commercial), administrative and criminal liability are used. Studies of the responsibility of the subjects of foreign economic activity contribute to the implementation of the state policy of ensuring the legitimacy in the sphere of foreign economic relations. 
Property liability applies in the form of pecuniary damages for direct, incidental damages, lost profits, pecuniary damages for non-pecuniary damage, as well as property sanctions.

Criminal liability in foreign economic activity is introduced only in cases provided for by the criminal legislation of Ukraine. The basis of criminal responsibility is the commission of a person of socially dangerous act, which contains the crime, provided by the Criminal Code of Ukraine.

Economic sanctions shall be applied to offenders on the grounds and in accordance with the procedure provided by the Economic Code of Ukraine, other laws and the contract. Economic sanctions are recognized measures of influence on the offender in the sphere of economy, as a result of which the economic and / or legal consequences for him occur. In the sphere of management the following types of economic sanctions are applied: compensation of losses; penalties; operational and economic sanctions. In this case, economic sanctions are applied in accordance with the procedure established by law on the initiative of participants in economic relations, and administrative and economic sanctions - by authorized bodies of state power or bodies of local self-government (Articles 216-218 of the Economic Code of Ukraine).

Offenses for administrative liability are offenses in the field of occupational safety and health; encroaching on property; in the field of nature protection, use of natural resources, protection of cultural heritage; in industry, construction and in the use of fuel and energy resources; in agriculture and for violations of veterinary and sanitary rules; transportation, road and communications; in the field of citizens' housing rights, housing and communal services and public works, etc.

Key words: legal liability, foreign economic activity, civil liability, economic and legal liability, administrative liability, criminal liability.

\section{Література}

1. Поєдинок В.В. Правове регулювання зовнішньоекономічної діяльності : навчальний посібник. Київ : Юрінком Iнтер, 2006. $288 \mathrm{c}$.

2. Омельченко А.В. Адміністративно-правові засади зовнішньоекономічної діяльності в Україні : монографія. Київ : KHEУ, 2011. 309 c.

3. Юридична енциклопедія : в $6 \mathrm{~m}$. / редкол. : Ю.С. Шемшученко та ін. Київ : Вид-во «Українськаенцииклопедія» імені М.П.Бажана, 1998-2004. T. 1. 2011. С. 430-431.

4. Про зовнішньоекономічну діяльність : Закон України від 16 квітня 1991 р. № 959ХІІ. Відомості Верховної Ради УРСР. 1991. № 29. Сm. 377 .

5. Цивільний кодекс Украӥни : Закон України від 16 січня 2003 р. № 435-IV. Відомості Верховної Ради України. 2003. № $40 . \mathrm{Cm}$. 356 .

6. Про міннародне приватне право : Закон України від 23 червня 2005 р. № 2709IV. Відомості Верховної Ради України. 2005. № 32. Cm. 422 .

7. Кримінальний кодекс Украӥни : Закон України від 05 квітня 2001 р. № 2341-III. Відомості Верховної Ради України. 2001. № 25. Cm.131.

8. Господарський кодекс Украӥни : Закон України від 16 січня 2003 р. № 436-IV. Відомості Верховної Ради України. 2003. № 18, № 19-20, № 21-22. Cm. 144 .

9. Кодекс України про адміністративні правопорушення : Закон України від 07 грудня 1984 р. № 8073-X. Biдомості Верховної Ради УРСР. 1984. № 51. Cm. 1122.

10. Митний кодекс України: Закон України від 13 березня 2012 р. № 4495-VI. Відомості Верховної Ради України. 2012. № 44-45, № 46-47, № 48. Сm. 1858 . 